\title{
Sappho Fragment 17: Wishing Charaxos a Safe Trip?*
}

\author{
Stefano Caciagli
}

Over the last 200 years, scholars of Sappho have concentrated on her audience and consequently her social role: according to various theories she was a teacher, a leader of a female religious group or an initiatory group, a trainer of choruses, a member of a companion group, and so on. ${ }^{1}$ Through a comparison between her and Alcaeus, I proposed in Poeti e società (2011) that Sappho was a member of a fairly stable group that consisted of both young and adult 'friends'. Although the core of her audience probably consisted of these 'friends,' ${ }^{3}$ Sappho's audience could change when the context changed, as Antonio Aloni

* In memory of Antonio Aloni. I would like to thank Prof. Anton Bierl, Prof. Claude Calame, Prof. André Lardinois, Prof. Jim Marks, Dr. Luna Martelli, Prof. Camillo Neri, and Prof. Renzo Tosi for the useful suggestions.

1 On Sappho as teacher, see Welcker $(1816)=(1845)$ 97-98, Müller $(1841)=(1865) 364-368$, and Wilamowitz (1913) 51; on the religious group see Wilamowitz (1913) 42, who argues that such a community could not exist in ancient Greece without a sacred aim [cf. Wilamowitz (1881) 274]; on the initiatory group, see Merkelbach (1957), Calame (1977), and Gentili (1984)= (2006) 138-161; on Sappho as trainer of a chorus, see Lardinois (1994) 79-80 and Ferrari (2007) 41-42; on Sappho's hetaireia see Parker (1993), Stehle (1997) 262-288, and Caciagli (2011) 285298. For a survey of Sappho scholarship see DeJean (1989), Lardinois (1994), Most (1996), and Caciagli (2011) 300-303. For Welcker and Wilamowitz see Calder (1998) 55-80. Sappho is also the object of reflections connected with gender studies: see Winkler (1990a).

2 Sappho's scholarship often assimilates Sappho's companions to the $\pi \alpha p \theta \varepsilon$ 'vol of her group: this hypothesis goes back to Welcker $(1816)=(1845)$ 97, who regards the $\mu \alpha \theta \dot{\eta} \tau$, $\alpha$ เ in Suda $\sigma$ 107 Adler as identical to the $\dot{\varepsilon} \alpha \hat{i} \rho \alpha$. However, the word $\dot{\tau} \tau \alpha \hat{p} \rho \circ \varsigma$ seems to imply a relationship between men who have the same social status and age (cf. e.g. Chantraine [1968-1980] 381); so, if the persona loquens in Sappho fr. 160 is the poet herself, the word $\dot{\tau} \tau \alpha i p \alpha$ in this poem may suggest that Sappho's audience consisted of her age-mates too. Moreover, in Ovid, Her. 15.199-202 Sappho's audience seems to consist of nuptae and nupturae, i.e. probably rovaixes and $\pi \alpha p \theta \varepsilon \dot{\varepsilon}$ ol. The idea of a group consisting of adults and young persons is congruent with the male hetaireia because young men attended the gatherings of this kind of group. See Bremmer (1990) and Caciagli (2011) 97-132 with bibliography.

3 I put 'friends' in inverted commas in order to signify the difference between modern friend-

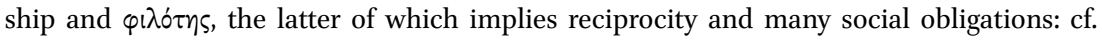
Benveniste (1969) I 335-353, Calame (2010) 19-23, and Caciagli (2011) 56-77.

(C) STEFANO CACIAGLI, 2016 | DOI: 10.1163/9789004314832_022

This is an open access chapter distributed under the terms of the Creative Commons AttributionNoncommercial 3.o Unported (CC-BY-NC 3.0) License. 
suggests. ${ }^{4}$ Thus, a large audience could potentially be present at 'public' ceremonies: for example, the whole city could attend the second part of the festival of the Adonia (fragment 140), ${ }^{5}$ which was performed outdoors, and the same can be said for wedding processions, whose function, among other things, was to publicise the legitimate union of the bride and groom. Sappho was involved in performances that took place in sacred spaces too, as we may infer from fragment 2. Here the composition of the audience was possibly influenced by the kind of ceremony: for example, it is possible to infer the attendance of Charaxos' family when fragments 5 and 15 were performed. ${ }^{6}$ Finally, the poet may engage in domestic celebrations similar to male symposia, as is suggested by fragment 22: in this context, the audience were possibly Sappho's 'friends' and companions, as in other sympotic performances.

The new text of Sappho published by Burris, Fish, and Obbink (2014) provides important insights into this question. The focus of my analysis will be fragment 17 , because I believe that this poem holds a liminal position in Sappho's corpus between a sacral and a family poem. However, I will survey the entire corpus of sacral and family poems by Alcaeus and Sappho to understand the meaning, context, and audience of this poem: in fact, in a 'pragmatic' approach, this kind of comparison is essential to fill the gaps in our knowledge. ${ }^{7}$

\section{Geographical Setting of Sappho Fragment 17: Messon}

Comparison between Sappho fragment 17 and Alcaeus fragments $129-134,{ }^{8}$ as well as analysis of later testimonia, shows that Alcaeus' divine triad in these two poems is the same (Hera karpophoros, Zeus hikesios and Dionysos omestes). In 1960, Louis Robert showed that Alcaeus fragments 129, 13ob and Sappho fragment 17 were probably performed in a place called Messon, north of the Kalloni

4 Aloni (1997) LVIII and 273-276.

5 The festival of the Adonia was spread over two days: the first day was set in a domestic context, while on the second the ritual was performed outdoors and was characterized by mourning like Sappho's in fr. 140: see Atallah (1966), Weil (1966), (1970), Detienne (1972), Burkert (1985) 176-177, and Caciagli (2011) 195-196.

6 See below.

7 On the pragmatic approach see Calame (1977) 29-32, (2008) 85-106, Vetta (1983), XIII-LX, Gentili (1984) = (2006) 15-47, Rösler (1984) 180-188, (1985) 138-142, (1997), Bierl (2003) 9899, Neri (2011) 22-24, and Caciagli (2011) 11-19. The pragmatic approach presupposes an oral society; see Havelock (1963).

8 As to the relationship between Alc. frs. 129-134 and Messon, see Caciagli (2010) 227. 
Gulf. ${ }^{9}$ Here there are the ruins of a temple, which were excavated by Robert Koldewey at the end of nineteenth century. ${ }^{10}$ The structure was built in the Hellenistic period ( 3 rd-4th centuries BC), but there is evidence of an archaic stratum. ${ }^{11}$ The location of this sanctuary in antiquity is important for understanding its religious functions: it was near the ancient road that connectedand indeed still connects - the west and the east parts of Lesbos, at the foot of the mountain that separates the territories of Pyrrha and Mytilene. ${ }^{12}$ The name of the site, Messon in antiquity, today Ta Mesa, is probably related to the fact that it is in the centre—political as well as geographical—of Lesbos. This gulf is a shelter for ships because of its natural setting, and the shrine of Messon was at the end of this bay. The archaeological site is now approximately one kilometre from the seacoast, but, as Kontis says, 'in antiquity the distance [between the temple and the coastline] would be significantly shorter, without the alluvium gathered later, near the beach. So the limit of the sacral precinct will have been located entirely beside the sea. ${ }^{13}$

\section{Messon between Myth and Rite}

The founding myths related to this shrine and the rites performed there are important for understanding the context in which fragment 17 was sung. However, Alcaeus and Sappho provide contradictory testimony. In fragment 129 Alcaeus implies that all the Lesbians have communally built the shrine ( $\tau \dot{\delta} \delta \varepsilon$

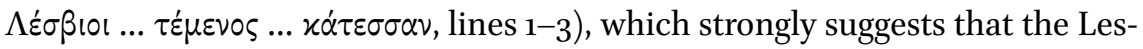
bians regarded Messon as their federal sanctuary (l. 3 Govov). ${ }^{14}$ My suspicion is that the poet also hints at the asylum that he found here, possibly because the federal role of this sanctuary preserved him and his fellows from violence at the hands of the Mytileneans, i.e. of Myrsilus' partisans. Furthermore, in light

$9 \quad$ See Fig. 8.1, p. 199. For the epiclesis of Hera see Robert (1960) and Caciagli (2010). For Messon see Robert (1925) and (1960), Calame (1977) 223-224, Nagy (1993) 221-225, Labarre (1994), Tsomis (2001) 46, Nagy (2007), Caciagli (2010), and Pirenne-Delforge and Pironti (2014). For Alcaeus fr. 129 see Robert (1960) 292-293 and 300-302; for fr. 13ob, ibid. 304305 and 314-315; for Sappho fr. 17, ibid. 314-315.

$10 \quad$ Koldewey (1890) 47-61.

11 See Labarre (1994) 423-424 and Spencer (1995) 22. For the archaic ruins see Koldewey (1890) 47-61, Acheilara (2004) 20, and Caciagli (2010) 247.

12 See Spencer (1996).

13 Kontis (1978) 352, my translation.

14 Cf. Robert (1960) 301-302 and Labarre (1994). 
of the long description of an oath in lines 14-23, it is a possibility that Alcaeus and his fellows had performed an oath at the site at some point in the past. ${ }^{15}$

Sappho fragment 17 seems to connect the present ḱóp $\tau \alpha$ (line 2) with the visit of the Atreid(s) to the shrine: because of the proximity of the archaeological site to the sea, Kontis suggests that there is a connection between this episode of the nostos and Messon. ${ }^{16}$ Here, according to Sappho, the Atreid(s) invoked Hera in order to find the best way home. Scholars agree ${ }^{17}$ that this myth is to be compared with Odyssey 3.141-175, where Nestor, Menelaus and Diomedes arrive on Lesbos and ask an unidentified god which route to choose in order to avoid the terrible storm that Athena plans. From the Odyssey (3.130-179), Ps.-Apollodorus (6.1) and Proclus (Chr. 277-286) we know that the Atreids argued before becoming separated; Menelaus set sail for Greece to avoid the storm, while Agamemnon remained at Ilion to appease Athena's anger. After the stop on Lesbos, Nestor and Diomedes safely arrived home, while Menelaus wandered further to Egypt (Od. 4.78-89). The rest of the Greek fleet under Agamemnon was afflicted by a terrible storm during which, among others, the Lesser Ajax perished, an episode recounted also by Alcaeus (fragment 298). However, this was not the only version of the myth known to the Greeks. The herald's account in Aeschylus' Agamemnon (626-680) implies that the Atreids left Ilion together, inasmuch as the storm caught them together. The tragedian

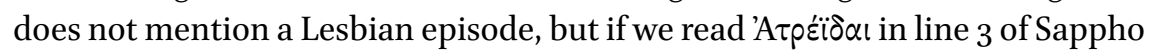
fragment 17 as nominative plural (cf. below), the story referred to by the poet is consistent with the one in the Agamemnon. ${ }^{18}$

The aition of Sappho fragment 17 may not contradict Alcaeus, because the latter could be referring to the founding myth of the sanctuary while Sappho to that of the feast of line 2. So the myth of fragment 17 could be related to one of what may have been a variety of functions served by this sacred place. The persona loquens of this poem, who implies the presence of the Lesbian triad in Messon already during the heroic age, asks the audience to take action according to ancient precedent (11-12). Hera is possibly summoned to perform the same service that she had performed in the past: because the Atreid(s) had difficulties in finding the good sea-route, it is attractive to think of the present prayer to the goddess as concerning sea voyages. ${ }^{19}$

\footnotetext{
15 This possibility was orally suggested to me by Prof. Claude Calame.

16 Kontis $(1978) 35^{2}$.

17 E.g. Page (1955) 59-6o.

18 See Page (1955) 60 and Nagy's contribution to this volume.

19 See Boedeker in this volume.
} 
The shrine was famous also for the Kallisteia, which Alcaeus seems to be witnessing in fragment 130b.17-20; this was a sort of annual beauty contest for women that included ritual cries. ${ }^{20}$ Hesychius ( $\mu 932$ Latte) mentions a federal

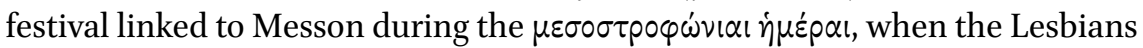
performed a communal sacrifice, ${ }^{21}$ and an epigram from the Greek Anthology (9.189) may refer to a chorus led by Sappho in this $\tau \dot{\mu} \mu \varepsilon v o \varsigma$. The epigram says that this shrine was dedicated to Hera $\gamma \lambda \alpha v \varkappa \hat{\omega} \pi \iota \varsigma^{22}$ an epithet that perhaps corresponds to $\gamma \lambda \alpha u$ xa in line 26 of Alcaeus fragment 129. Be that as it may, in this poem Hera has a strange epiclesis, since she is here a karpophoros (l. 7 $\pi \dot{\alpha} \nu \tau \omega \nu \gamma \varepsilon v \varepsilon \dot{\varepsilon} \theta \alpha \nu) ;{ }^{23}$ this epithet may be connected to the rich ground that the shrine occupies. However, nothing proves that the chorus led by Sappho in the epigram from the Greek Anthology was involved in the Kallisteia festival: we can also imagine that whoever wrote this epigram may have had in mind various allusions by Sappho to Messon and combined them with the fact that many of her poems display connections with choral performances.

This survey shows that the rituals at Messon were possibly of different kinds. It is speculative to relate Alcaeus fragments 129-134 and Sappho fragment 17 to specific rites such as the Kallisteia without a meticulous analysis of all the ele-

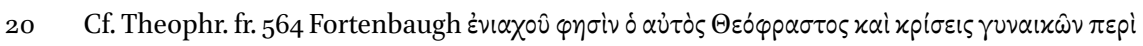

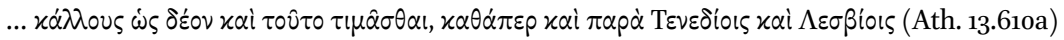

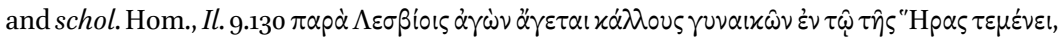

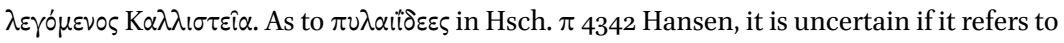
the Lesbian Kallisteia: see Caciagli (2010) 239-240. For ó $\lambda \dot{0} \lambda u \gamma \alpha$ cf. Alc. fr. 13ob.20.

21 The adjective 'mesostrophonios' that names the days in which - according to Hesychius-

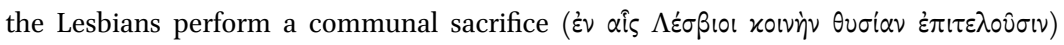
possibly hints at Messon: its meaning is perhaps 'when (the Lesbians) move on towards Messon.' See Robert (1960) 303-304.

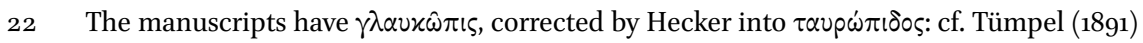
567 n. 11, Page (1981) 338, and Caciagli (2010) 234.

23 I follow Picard (1946) 46of. and Robert (1960) 285-300, who assume that the Hera of fr. 129 is a fertility goddess. Cf. Liberman (1999) 62, Gentili-Catenacci (2007) 182, Neri (2011) 223. Contra Hutchinson (2001) 198, who does not consider Robert's arguments about the link between the goddess of Messon and some Lesbian Roman inscriptions that assimilate

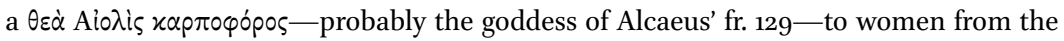
imperial family. Furthermore, Pirenne-Delforge and Pironti (2014) 27 say that the Hera of fr. 129 is 'une sorte de Genetrix "de tous" plutôt que "de toutes choses" ou "de tout": if there is nothing in the grammatical structure of these lines which implies this latter interpretation, we may take into account that a Hera karpophoros was in Argo and in the Sele estuary and that these Heras were possibly similar to the Hera in Messon. See Caciagli (2010) 231-234 with bibliography. 
ments provided by these fragments. Given the prominence of Messon in Lesbos from the archaic period onwards, ${ }^{24}$ and since the testimonia attest several rituals performed here, it is likely that different rites were took place at the same site at different times, possibly with different audiences too. Obviously, this caution applies to the supplements for the lacunae in fragment 17 too, which should not be based on the preconceived notion that fragment 17 is connected with the Kallisteia or other specific rituals.

\section{The incipit of Sappho Fragment 17}

It is difficult to make sense of what ritual the founding myth in fragment 17 refers to, in part because the incipit and the explicit contain many lacunae. An imperative is of course likely at a beginning of a prayer such as fragment 17 , but many elements remain problematic in the first stanza of this poem. First

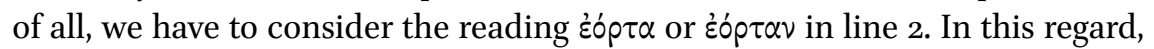
$\tau \dot{\alpha} v$ in line 3 may have to be construed with źóp $\tau \alpha(v)$, since this is the nearest

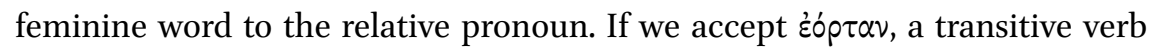
or a preposition would be required to support this accusative; so $\sigma \dot{\alpha}$, which is required by the metre and is probably a nominative, has to relate to a word in the nominative. In this framework, if we accept Joel Lidov's idea that 'any reconstruction should avoid the mistake ... of ... taking it (i.e. $\pi \lambda \dot{\alpha} \sigma \circ \mathrm{v})$ with the dative', it is difficult to suppose that the word following $\pi \lambda \dot{\alpha} \sigma 10 v$, which ends in -olc, is not an accusative. ${ }^{25}$ So, given the reading źóptav, we have to assume that what follows $\pi \lambda \alpha^{\prime} \sigma 10 v$ is coordinated with this accusative, e.g. as

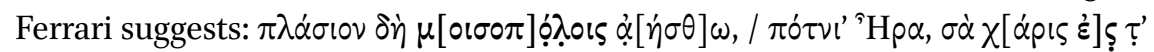

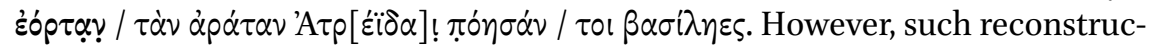
tions may render the syntactic structure of the first stanza a little too complex,

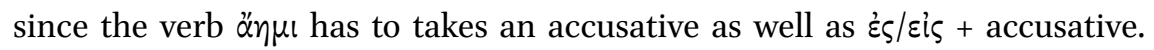
In regard to Ferrari's reconstruction, we may also note that the expression $\ddot{\alpha} \eta \sigma \theta \alpha \mathrm{l}+\dot{\varepsilon} \varsigma / \varepsilon \dot{\imath} \varsigma$ accusative seems to be unattested. ${ }^{26}$ Given that it is tempting to accept the conjecture $\dot{\alpha}[\gamma \varepsilon \dot{\varepsilon} \sigma \theta] \omega$ proposed by Burris, Fish, and Obbink

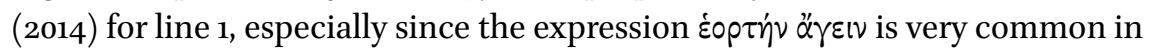
Greek, I suggest that ćóp $\tau \bar{\alpha}$ (preceded by an adjective) may be the more likely

\footnotetext{
24 See Labarre (1994).

25 Burris, Fish, and Obbink (2014) 19; cf. Lidov (2004) 390-393: $\pi \lambda \dot{\alpha} \sigma 10 v$ is 'used absolutely or takes the genitive (and $\mu$ [ov is not Lesbian)'.

26 See $T h L G$ I $797-798$ s.v. پٌं $\mu$.
} 
reading. After $\pi \lambda \dot{\alpha} \sigma \circ{ }^{\prime}$, in my opinion, the likely reading is $\mu[\varepsilon \lambda \pi \circ] \mu \mu^{\prime} \operatorname{col}_{0} \sigma^{\prime}(\mathrm{\iota})$ because the idea of a chorus that dances during a feast is absolutely congruent: the dative is not a real problem to this reconstruction, despite what Lidov says. ${ }^{27}$

The other problems in the first stanza are the case of 'A $\tau \rho[\varepsilon i \bar{\delta} \alpha]$ ! along with its number and the meaning of $\dot{\alpha} p \dot{\alpha} \tau \alpha \nu$ in line 3. The meaning of $\dot{\alpha} \rho \dot{\alpha} \tau \alpha \nu$ is tricky. If a verbal adjective is necessary (see below), I consider unlikely the interpretation advanced by Burris, Fish, and Obbink: 'the festival which, having been prayed for by the Atreid [sc. Menelaus], the kings performed etc..'28 The same goes for 'your ... festival ... which the Kings, the Atreidai, established on a vow', which Obbink proposes in the first chapter of this volume, following West's interpretation. ${ }^{29}$ As regards the first reading, I find it improbable that someone would pray for a festival: a deity may be invoked, but not a celebration, which can be at most performed. In fact, a festival is the means to invoke or celebrate

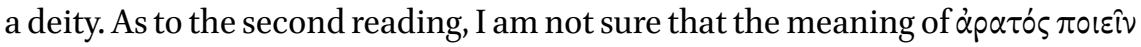

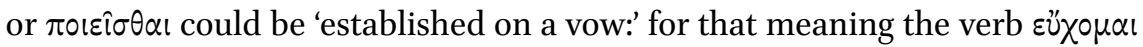
is used, not $\alpha \rho \alpha \mu \alpha .^{30}$ So I suggest that $\alpha$ $\rho \dot{\alpha} \tau \alpha \nu$ means neither 'prayed for' nor 'established on a vow.' One of the testimonia of the poem, PSI 123, provides a suggestive clue. In this papyrus, the scribe glosses $\alpha \dot{\alpha} \alpha \dot{\tau} \alpha \nu$ with ह̇pád $\tau \alpha \nu .{ }^{31}$ Even though this adjective is contra metrum, its meaning may be of interest: 'the lovely feast.' I think it likely that the scribe of PSI 123 was troubled by 'prayed for' and suggested a more likely meaning. Here àpó $\tau \alpha \nu$ possibly means 'attractive' or

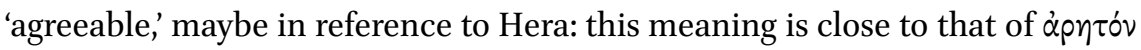

27 I should like to note that Lidov's idea about $\pi \lambda \dot{\alpha} \sigma$ เov is not strictly necessary: cf. Neri (2014) 14, translated by Chiara Meccariello (see http://www.papyrology.ox.ac.uk/Fragments/ Translation.Neri.i.15.pdf): 'the "few apparent instances" of the adverb with the dative are not so few after all, if one considers, for example, such passages as $O d$. 7.171 ö oi $\pi \lambda \eta \sigma$ iov

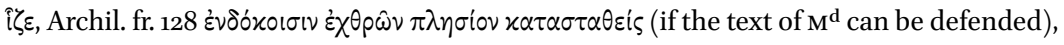

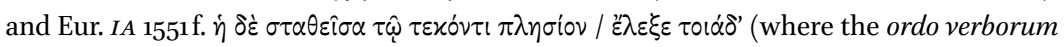
makes it certainly preferable for the dative to be governed by $\pi \lambda \eta \sigma i o v$ rather than $\varepsilon^{\prime} \lambda \varepsilon \xi \varepsilon$ ), and the fact that the adjective $\pi \lambda \eta \sigma i o s$ and the verb $\pi \lambda \eta \sigma i \alpha \zeta \zeta \omega$ are regularly constructed with the dative'.

28 Burris, Fish, and Obbink (2014) 19, 21.

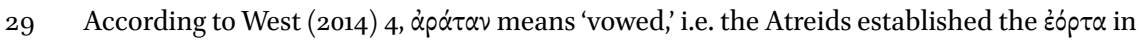
fulfilment of a vow. Cf. Ferrari (2014) 17 and Nagy in this volume.

$30 \quad$ There seem to be no examples of äp $\alpha \mu \alpha \mathrm{l}$ having the meaning of 'establish something on a

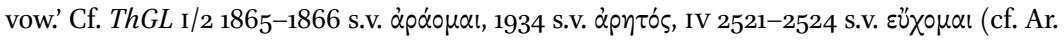

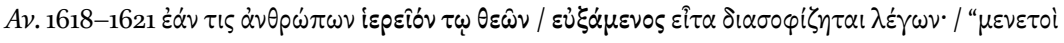

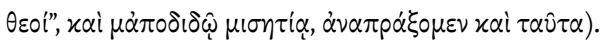


in Callimachus (Del. 205), where Leto 'gladly (i.e. in a agreeable, appropriate way) ceased from her grievous wandering.' ${ }^{32}$

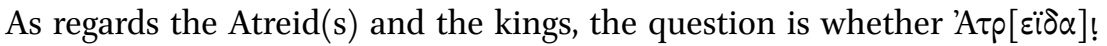
is to be interpreted as a nominative plural or as a dative singular. In the editio princeps, Burris, Fish, and Obbink ${ }^{33}$ prefer the dative for the following reasons:

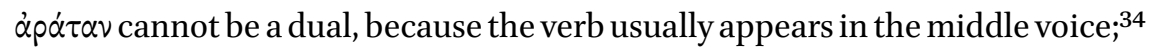

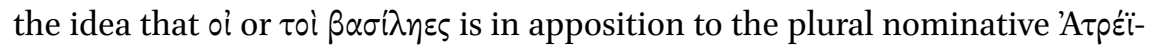
$\delta \alpha l$ is 'cumbersome and so perhaps unlikely'. Burris, Fish, and Obbink maybe prefer this interpretation because at Odyssey 3.167-175 only Menelaus lands on Lesbos, while Agamemnon remains at Ilion. In any case, the understand-

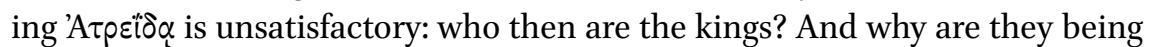
summoned with a deictic, if we read $\tau o$ in in line 4 (see below)? Burris, Fish, and Obbink (2014) rightly link the kings to the ancestors of the ruling Lesbian aristocracy in the archaic age, recalling fragment $130 a .15$ of Alcaeus, where $\tau \varepsilon i x$ ' $\beta \alpha \sigma i \lambda \eta^{\prime}$ iov seems to refer to Hera's sanctuary at Messon (cf. also $\beta \alpha \sigma i \lambda \eta \alpha \nu$ " Hp $\alpha \nu$ in line 6 of the Brothers Poem), but they do not consider the social implication of the use of the word $\beta \alpha \sigma i \lambda \varepsilon \dot{s} \varsigma$ on Lesbos.

Before analysing this question, I would make some comments about the end of the stanza: with regard to the accent in P.GC. inv. 105 fragment 2 col. II line 12 $\tau o$... [, Burris, Fish, and Obbink say that this accent probably implies something other than an article, possibly a demonstrative. However, firstly the reference of a deictic demonstrative may be difficult to be understood; secondly, according to Neri, 'the nominative plural of the article (also as a demonstrative) is always

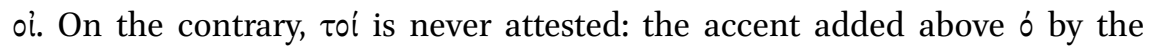
corrector may indicate the divisio $\tau$ ' oi'. ${ }^{35}$ Moreover, ' $\tau$ ' $(\varepsilon)$ is out of place without a verb coordinated with $\pi$ ón $\sigma \alpha v$ '. In light of these arguments, I would propose that the verb of the relative clause is $\pi \operatorname{lo}^{\prime} \sigma \alpha \nu \tau^{\prime}(\circ)^{36}$ and that we cannot rule

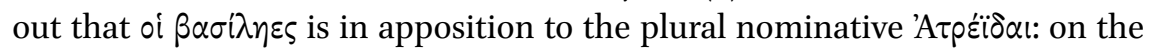
contrary, this is likely from a historical and social point of view.

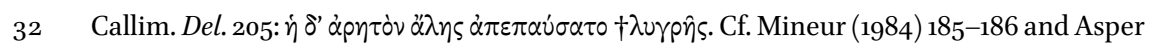
(2004) 431 .

33 See Burris, Fish, and Obbink (2014) 19-21.

34 The dual seems to be unattested in Lesbian; cf. Neri (2014) 15.

35 Neri (2014) 14, translated into English by Chiara Meccariello.

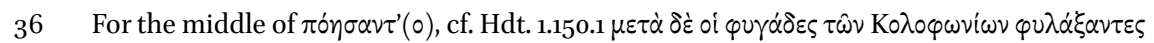

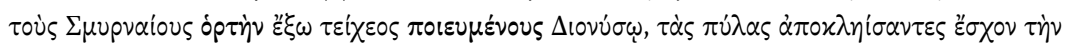
$\pi \dot{\lambda} \lambda$ เv. Cf. Neri (2014) 15-16. 


\section{The Atreids in Fragment 17}

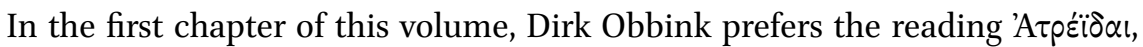
i.e. a plural nominative: I suggest that this interpretation is congruent with the presence of $\beta \alpha \sigma^{i} \lambda \eta \varepsilon \varsigma$ in line 4 and, more generally, with the social history of Lesbos. The word $\beta \alpha \sigma i \lambda \varepsilon$ ús is politically important in Lesbos, where the term was used to refer to the highest office. ${ }^{37}$ However, this word is not neutral. In fact, Lesbian $\beta \alpha \sigma i \lambda \varepsilon i \varsigma$ were in particular the Penthilidae, i.e. the royal genos of Lesbos: ${ }^{38}$ they were divested of authority probably during the 7 th century, but retained some measure of influence (at least) until Pittacus' regime. ${ }^{39}$ The Penthilidae claimed to be descended from the Atreids; thus, for example, Alcaeus refers to this genos as 'A $\tau \varepsilon \varepsilon i \bar{\delta} \alpha \nu$ in fragment 70.6. Furthermore, these Penthilidae, who claimed to be descendants of Agamemnon's son Orestes, were held to be the leaders of the Aeolic colonisation of Lesbos. ${ }^{40}$

As to this colonisation, according to P.Oxy. $3711,{ }^{41}$ one of the religious epi-

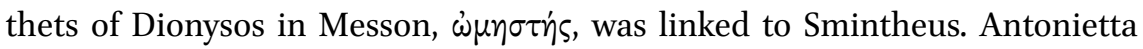
Porro suggests a connection between this Smintheus and the colonisation of Lesbos: ${ }^{42}$ in fact, according to Plutarch (Sept. sap. conv. 163a-d), Smintheus' daughter was offered to the Nereids and Amphitrite in order for the colonisation of the island to proceed. If P.Oxy. 3711 actually connects this myth with the sanctuary of Messon, it is possible that the legend said that the colonists landed at Messon. ${ }^{43}$

It is difficult to detect in the myth any Lesbian kings other than the Penthilidae, especially in a context in which one or both Atreidae are summoned. As a consequence, retrojection of the ancestor of the Penthilidae on Lesbos back

37 See Mazzarino (1943) 43 and Carlier (1984) 460.

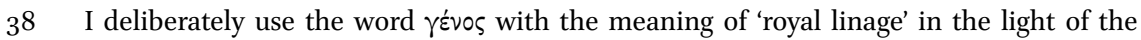
arguments of Bourriot (1976) and Roussel (1976). For the $\beta \alpha \sigma i \lambda \varepsilon \hat{\imath}$ in Lesbos see Carlier (1984) $456-45^{8}$.

39 For the Penthilidae, cf. Arist. Pol. 5.1311b.26-30, Strab. 13.1.3, Plut. De soll. an. 984e, Conv. sept. sap. 163a-d, and Paus. 3.2. Cf. also Carlier (1984) 458-461.

40 See Lentini (2000) 4-5 and Ferrari (2007) 33-34.

41 See P.Oxy. fr. 1 col. II l. 13-16.

42 See Porro (1994) 172.

43 See Porro (1994) 172-173. However, Shields (1917) 1-2 postulates that the colonists of Lesbos landed on Methymna. In fact, Anticlides of Athens (FGrHist $140 \mathrm{~F} 4$ ), quoted by Athenaeus (11.466c), says that a girl was thrown overboard by the colonists as an offering to Poseidon; after some time, her lover Enalos, who followed her into the waves, extraordinarily arrived alone at Methymna. 
to the heroic age would be a sort of legitimation for the ensuing Aeolic colonisation: this particularly applies if Agamemnon attends the festival referred to in line 2, because he was supposedly Penthilus' grandfather. The fact that the Atreids are the Lesbian $\beta \alpha \sigma \lambda \lambda \varepsilon i \varsigma$ par excellence, and that the reference to 'kings' would be unintelligible without a link to the legendary brothers suggests that

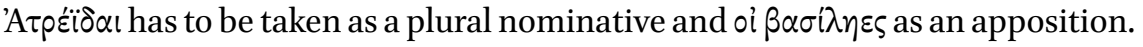
So I suggest the following translation of lines 2-4: 'let there be celebrated, lady Hera, your ... festival, which, agreeable to you (i.e. it propitiates Hera), the kings Atreids celebrated for themselves. ${ }^{44}$

In conclusion, fragment 17 testifies to a different version of the Atreids' nostos from Odyssey 3: the first two stanzas of Sappho's poem seem to concern the founding myth of the festival mentioned in line 2 , and this subject matter seems to be connected with the problem in the myth of finding a sea route. The existence of different versions is characteristic of Greek myth: Sappho chose this version - or simply used the only one she knew $^{45}$ - perhaps because of the importance of the Penthilidae in Lesbos; for this reason, the presence of both Atreids in Messon has a political and cultural motivation, also in connection with the Aeolian colonisation.

\section{Sappho Fragment 17 and the Kallisteia}

Scholars have sometimes connected fragment 17 with the Kallisteia, and used this hypothesis to fill the lacunae of this text. ${ }^{46}$ However, taken together, the evidence of the epic tradition, the location of Messon, and lines 6-8 strongly suggest a connection between fragment 17 and the difficulties encountered during a sea journey. So I think that the festival mentioned in line 2 does not correspond to the Kallisteia. The function of the Kallisteia festival is complex, and may be connected with an initiatory process, in which case the beauty

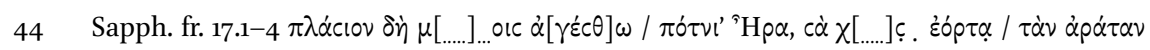

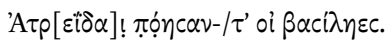

45 I am not really convinced by the hypothesis that Aeolic poets knew the Homeric poems: there is no evidence that they knew the Iliad and the Odyssey and, in fact, it is very hard to find reliable quotations of these poems in Sappho and Alcaeus. The poems that sound like epic, e.g. Sappho's fr. 44, deal with episodes that are not Homeric but Cyclic. See Caciagli (2011) 15 and (2014) 6o. Contra West (2002).

46 See West (1970) 327, Calame (1977) 223-224, (2009) 4-7, and Burris, Fish, and Obbink (2014)

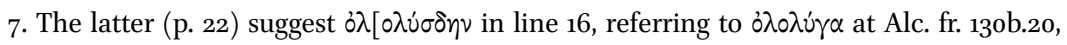
where the context is the Kallisteia. 
contest would represent the transition to the status of adult women. ${ }^{47}$ The purpose of this festival is beyond the scope of the present argument, but I note that fragment 17 attests the presence at the performance of both women

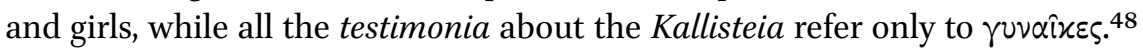
Obviously, it is possible that young girls were present at the Kallisteia, but it may be significant that, according to the testimonia, adult women were the leading participants in this ceremony: if the Kallisteia were an initiatory ceremony, it would be strange for the $\pi \alpha p \theta \varepsilon$ vo not to be mentioned by the sources. The founding myth does not concern the beauty contest anyway, and there are no hints of the Kallisteia in fragment 17: the poem concerns a return home over the sea, and the present request is possibly connected to this question, as is suggested by $\dot{\alpha} \pi i x \varepsilon\left[\sigma \theta \alpha \mathrm{l} v e l\right.$ similia in the last line of the poem. ${ }^{49}$ These considerations probably preclude identification of the Kallisteia with the festival performed in fragment 17 .

\section{The Brothers Poem and the Occasion of Sappho Fragment 17}

Before the publication of the new Sappho texts I had already suggested that fragment 17 concerns Charaxos: he is the only person linked with Sappho who sailed the seas as the Atreids did. ${ }^{50}$ Therefore, I postulated that, through fragment 17 , Sappho along with her friends and maybe family members seeks the protection of Hera and her paredroi Zeus and Dionysos, ${ }^{51}$ so that Charaxos may find the proper sea route and arrive safely on Lesbos. Apart from the mythological part of fragment 17 , I have based this hypothesis on the theme of Sappho fragments 5 and 15 . The new text of fragment 17-especially lines $7-$

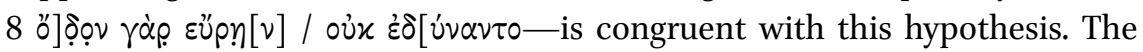
fact that the Atreids petitioned Hera for a route to leave Lesbos and that Charaxos' friends ask her that he find the route to return to Lesbos are not in contradiction with each other: it is possible to suggest that the mythical episode

\footnotetext{
47 See Brelich (1969) 338-340 and Calame (1977) 223-224.

48 See below.

49 See Neri (2014) 18.

50 See Caciagli, L' usage du mythe chez les poètes éoliens (forthcoming), (2010) 236-227, and (2011) 153-156, as well as Neri (2014) 22. For Charaxos' troubles at sea, see Sappho fr. 15.1-8 [according to Fraenkel's (1928) reconstruction], the Brothers Poem, and Ovid Her. 15.6588. For Charaxos as a merchant seaman (especially in wine), cf. Strab. 17.1.33 and Ath. 13.596b; see also Caciagli (2011) 250-269.

$5^{1} \quad$ For the function of Zeus and Dionysos in the Lesbian triad see Picard (1946).
} 
that concerned the Atreids was the aition of one of the functions of the Messon sanctuary, i.e. the protection from the dangers of the sea. Moreover, the aim of the Atreids and Charaxos is to return home. If the $\beta \lambda \dot{\alpha} \beta \eta$ that Charaxos can

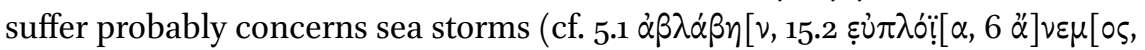
$7 \lambda i[\mu] \varepsilon v \circ \varsigma)$, the Atreids possibly had to find a route to avoid the storm that Athena planned.

The Brothers Poem, which is clearly not a religious poem of the type that fragment 5 probably is ${ }^{52}$ possibly provides fresh perspectives on this hypothesis. The persona loquens uses a first person plural that may or may not include

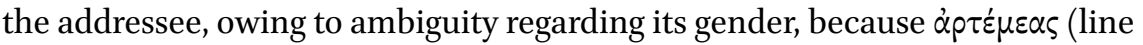
13) could be masculine or feminine. In any case, the poet probably addresses a relative or a close friend, since we are led to believe that the addressee is deeply concerned with Charaxos' situation. In regard to this addressee, it is significant that we can identify him with one of the following figures: one of Sappho's parents, Scamandronymos or Cleis; one among her brothers, e.g. 'Eurygyios'; 53 a friend of Charaxos or Sappho; or a member of their less immediate family, such as a cousin or brother-in-law. ${ }^{54}$ First of all, we have to consider the leading role played by the addressee, so much so that the addressee can send Sappho to pray to Hera: for this reason it is unlikely that the addressee is one of Charaxos' friends or distant relatives. It is possible to dismiss Sappho's father too: if the Ps.-Ovidian Epistula Sapphous (61-62) is to be trusted, ${ }^{55}$ he died

$52 \quad$ Following an oral suggestion by Neri, I take fr. 98 and the Brothers Poem to be a prelude of sorts to ritual songs; so the Brothers Poem would be an 'introduction' to fr. 17.

53 For the name of this Sappho's brother see Di Benedetto (1982) 217-219. Eurygyios, a spelling consistent with Eúpúyıৎ in Suda $\sigma 107$ Adler, is possibly the correct reading in P.Oxy. 1800

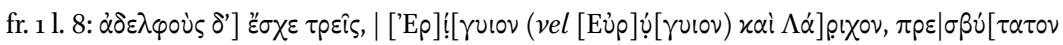
$\delta \dot{\varepsilon} X \dot{\alpha} \rho] \alpha \xi o v$. The editor princeps of this text, Hunt, prefers the reading ['Ep]![rviov on the basis of Arr., Anab. 3.6.5 (cf. Diod. Sic. 17.81.3), where it is said that a general of Alexander the Great was called 'Epirvios $\delta$ L $\alpha$ pixov, and Suda $\sigma 107$ Adler, where one of Sappho's father names is 'Hpirvos, possibly a corruption of 'Epirvios. If in fr. 213Ah.40-41

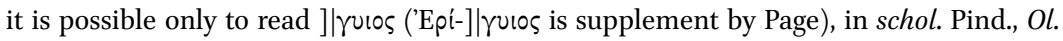
10-11 D.- a biographical epigram - the name of Sappho's father is Eủpurúov, metrically guaranteed. So, there is no good evidence that the name of Sappho's third brother was Erigyios.

54 Bettenworth (2014) suggests that Sappho's wet-nurse is the addressee, on the grounds that the attitude of the poet in l. $5(\theta \rho \dot{\lambda} \lambda \eta \sigma \theta \alpha)$ might have been too aggressive if the addressee was Sappho's mother Cleis (cf. Obbink [2014] 41 and Ferrari [2014] 4). In any case, I think that a wet-nurse could hardly have had the authority to send the poet to Messon.

55 The sources of the Epistula Sapphous are obscure, but it is likely that its author knew Sappho's poetry: even if the story of Phaon was mainly based upon comedies that dealt 
when the poet was a child. As for Sappho's mother, I am not convinced that a woman could play such a leading role in archaic Greece, especially when it was necessary to make a long trip in order to pray to Hera (the distance from Mytilene to Messon is approximately 30 kilometres). At any rate, we have to consider that the persona loquens will not go unbidden to Hera, but a $\chi \dot{\varepsilon} \lambda \varepsilon v \sigma \mu \alpha$ is required. ${ }^{56}$ Why would an adult woman like Sappho have to be subordinate to her mother? And why could her mother not go herself? Charaxos and Larichos are excluded by the text itself: the narrator complains that Larichos is too young to raise his head, while Charaxos, who was Sappho's eldest brother and probably the leader of her family after Scamandronymos's death, is obviously absent.

So it is possible that the addressee - and the head of the household during Charaxos' absence - was Eurygyios, ${ }^{57}$ Sappho's third brother. We do not know whether he was older than Larichos, but this may perhaps be inferred from the fact that in P.Oxy. 1800, a biography of Sappho, the name of Eurygyios appears before that of Larichos and Larichos is perhaps referred to as $\left\langle\nu \varepsilon \dot{o v\rangle}\right.$ oै $v \tau \alpha .{ }^{58}$

with the poet, some elements could be inferences drawn from her verses, for which reason it may be mistaken simply to dismiss a "fact" like Scamandronymos' death. Cf. Knox (1995) 278-279.

$5^{6}$ Sappho has to ask someone in order to go to Messon (1. 9-10): even if the poet has a leading role in her group, it seems to be necessary that she be prompted to attend the sanctuary. I suggest that only the (male) leader of her faction or family could perform this task. As for the poet's mother Cleis, it is difficult to read $\mu \alpha$ [ [hence $\mu \hat{\alpha}[\tau \varepsilon \rho$ by West (2014) 9] in P.Oxy. 2289 fr. 5 , i.e. in the incipit of Brothers Poem: in fact, a comparison to frs. 2.1 and 4.4 of this papyrus seems to show that the stroke on the right of the $\mu$ in fr. 5 is part of $\mu$ itself and not of a possible following $\alpha$. Furthermore, I am not convinced that Sappho's mother was still living during Charaxos' affair, which possibly dates between $585-57$ о вС, given

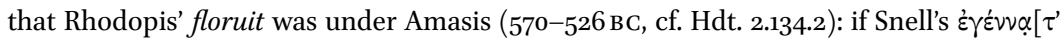
$\varepsilon^{\natural} \varphi \alpha$ in fr. 98 a.1 or similia are acceptable supplementa, the past tense of $\varphi \eta \mu$ i would even suggest that Cleis had died in the first decade of the 6th century вс, i.e. during Pittacus' government. This assumption is not in contradiction with the fact that Larichos is young in the Brothers Poem, possibly closer to becoming an adult (cf. lines 21-22) if Charaxos' affair takes place 15 or 20 years after the seizure of power by Pittacos. According to Ferrari (2014) 1, who goes by the evidence from Ancient Chronographs, Sappho was born between $640-630$ BC and, consequently, Charaxos' affair dates to 620-610 BC; however, this dating is not consistent with Rhodopis/Doricha's floruit. For the chronology of Lesbian history see Mosshammer (1979) 246-254. On the relationship between Doricha and Rhodopis see Caciagli (2011) 250-261.

57 See also Lardinois (2014) 191 and Lardinois's contribution to this volume.

$5^{8} \quad$ See $n .53$. 
Given the lack of testimonia about Eurygyios' behaviour, it is difficult to guess why, if he was - as I have proposed — the temporary leader of Sappho's family, she hoped that Larichos became a man. In any case, it is important that Sappho invites the addressee to send her to Hera, whose epithet is significantly $\beta \alpha c i \lambda \eta_{n} \alpha \nu$ (cf. also Zeus in line 6). This sentence probably hints at Messon. So, according to the Brothers Poem, Sappho wants to entreat Hera for Charaxos' safety along with that of the cargo, herself, her interlocutor and possibly her audience

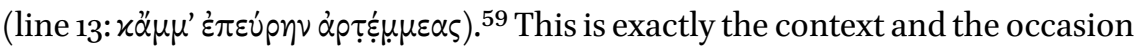
that I have postulated for fragment 17.

\section{Sappho Fragment 98, the Brothers Poem, and the Composition of Sappho's Audience}

I have dealt so far with the persona loquens in the Brothers Poem, the women and girls in fragment 17 , and the audience of these poems. If we accept that Sappho addresses a relative in the Brothers Poem, possibly Eurygyios, we would have a situation quite similar to that of fragment 98 . Here, Sappho talks about her mother and speaks to her daughter, possibly hinting at family difficulties. Fragment 98 is a difficult text and the obeloi in lines 1-3 of fragment $98 \mathrm{~b}$ (P. Mil. $3^{2}$ ) prevent an easy reconstruction of poem, ${ }^{60}$ but fragment 98 a (P. Haun. 301) does seem to recall the words of Sappho's mother: when she was young, there was no embellishment for the hair other than a ribbon or crown of flowers. However, since wearing mitras from Sardis had recently come in vogue, this fragment apparently focuses on fashion. Fragment $98 \mathrm{~b}$ entails several interesting possibilities as regards its possible audience. ${ }^{61}$

59 See Pirenne-Delforge and Pironti (2014) 28. As to the link between the Brothers Poem and fr. 17 , see n. $\mathbf{5}^{2}$. I suggest that fr. 17 has a wider audience than Sappho and her interlocutor because of the possible social role of Sappho's poetry: in my view, e.g. frs. 1, 16, 22, 27, 31, 71, 94, and 96 offer a set of paradigmatic situations for Sappho's female group and her audience in general. So, when the poet speaks about herself or her audience, the content of her poem is also addressed to her friends and her listeners in general. See Caciagli (2011) 148-149, 175-176, 245-249. The archaic sympotic poems may provide parallels to this situation: e.g. a poem to a companion — cf. e.g. fr. 38 a by Alcaeus or fr. 14 by Archilochosmay be ideologically important for the sympotic group.

6o Neri (2012) provides a recent survey of the status quaestionis of Sapph. fr. 98 .

61 Cf. Ferrari (2007) 11-26. 


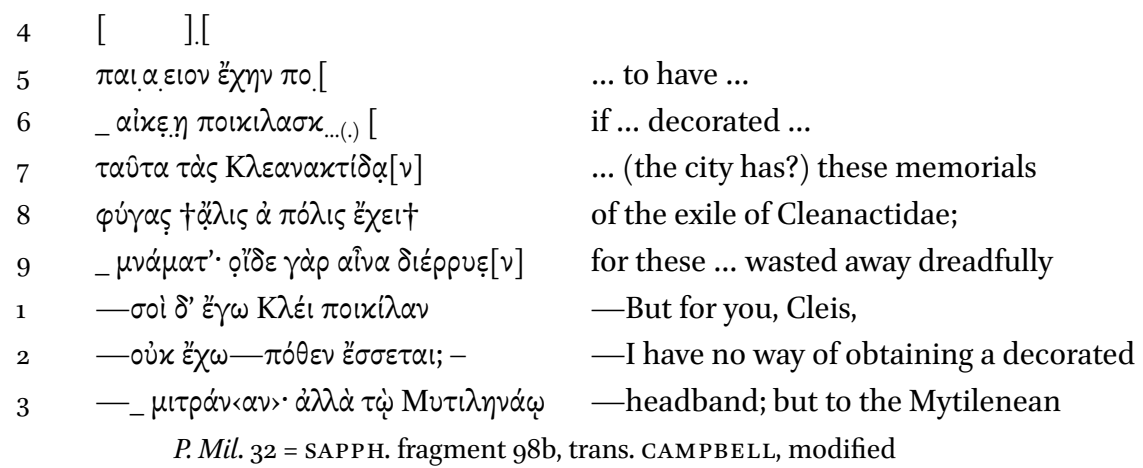

The fragment is in a terrible state:62 lines $4-6$, which are actually at the beginning of the Milan fragment, possibly addresses the subject of fashion too, in that

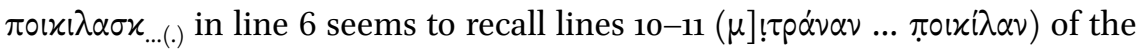
Copenhagen fragment; Sappho probably went on to suggest that the current situation in the city (lines 8-9) is linked to the exile suffered by the Cleanactidae. Three lines with obeloi follow, in which Sappho says that it is impossible to find a mitra for her daughter. It is likely that these lines belong before lines 49 in fragment $98 \mathrm{~b}$ and that they follow fragment $98 \mathrm{a}$, which also mentions a

62 I prefer-and I follow - the reading of Mazzarino (1943) 51-61 to that of Page (1955) 102103: see Caciagli (2011) 210-211. According to Page (1955) 102, 'Sappho tells her daughter that she cannot provide her with fashionable attire (l.1-3); such things are indeed obtainable in Mytilene, but there the Cleanactidae are in power-they are reminders of the time when our enemies were in exile (l. $7-8)$ and we were in the city; now they are in the city and we are in exile; our fine clothes are all worn out, and we have no means of obtaining more'. So Page reads $\alpha{ }^{\prime} \delta \varepsilon$ in l. 9, saying that this pronoun cannot be connected with $K \lambda \varepsilon \alpha \nu \alpha \chi \tau i \delta \alpha \nu$ because it refers to the succeeding text in the Greek, not to the preceding one. However, in 1.9 the reading is probably ọi $\delta \varepsilon$ because the omicron is written in the same way as those in lines 1 and 8; furthermore, a tendency is not a law, so o' $\delta \varepsilon$ could in fact refer here to K $\lambda \varepsilon \alpha \nu \alpha \dot{\alpha} \tau \iota \delta \alpha$ [cf. Alc. fr. 70.2, Sapph. fr. 27.6, Soph., Ant. 449, and Hdt. 1.137.1. See also Schwyzer, GG II 209, LSJ ${ }^{9}$ 1198, Bailly 1350, and Gentili-Catenacci (2007) 153]; anyway, the contrast between $\tau \alpha \hat{v} \tau \alpha$ and o'ð $\delta$ could have a spatial meaning: see Neri (2012) 39. In Page's reading the link between the clothing and the demonstrative pronouns is vague, which does not explain the allusion to the man from Mytilene. Finally, it is unlikely that an aristocrat would have been unable to find a Lydian mitra while in exile, given that such wares were available outside Lesbos too (cf. Alcm. fr. 1.67-68); this being the case, the simple fact of the exile does not necessarily explain the poverty suffered by Sappho's family, and indeed guest-host relationships, e.g. such as those enjoyed by Sappho with Syracuse (cf. Marmor Parium ep. 36), provided financial help to exiles. See Neri (2012) 3942. 
mitra. These obelized lines are important for understanding the meaning and the audience of this poem. Up until this point the text seems concerned with fashion and grace, obviously a favourite theme of Sappho's. This is suitable for a

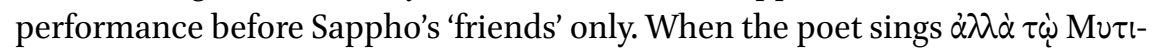
$\lambda \eta \nu \alpha \dot{\omega}$ (line 3), however, she marks a turning point, in effect connecting the lack of the mitra with the political situation in her city, as is implied by lines 49 .

I suggest that it is more likely that the 'Mytilenean man' is Pittacus, who possibly enacted a sumptuary law of the type promoted by sages and lawgivers in archaic Greece. ${ }^{63}$ If this was indeed the case, imported consumer goods such as a mitra would have been hard to find in Lesbos during his government: 'the lack of a mitra is the souvenir that the city has of the exile suffered by the Cleanactidae, because this faction is terribly scattered, ${ }^{64}$ i.e., when the Cleanactidae were in power, the mitra was available in Lesbos. So fragment 98 would be more than a poem about habrosyne: it would-I suspect—address the specific difficulties of Sappho's family's faction. I also suspect that a poem like this could have had a wider audience than just Sappho's female 'friends'. Lines 4-9 of the Milan fragment suggest an audience involved in politics and concerned with the difficulties of the Cleanactidae. If the attendance of Sappho's male relatives at the performance of fragment 98 is to be seriously considered, then it is more difficult to determine the occasion of this poem: in what context would male and female relatives have attended performances in which a 'private' theme like the complaint by Sappho's daughter about the lack of a mitra would have been suitable? Given the concern expressed over the ornament, fragment 98 was perhaps sung as a religious festival was approaching, but the themes of this poem suggest a sympotic atmosphere. The presence of women and men together seems to rule out this possibility, however, especially if Sappho was an aristocrat and not a courtesan, the latter possibility have been defended by Renate Schlesier. ${ }^{65}$ So I may suggest a family domestic gathering or, at least, a

\footnotetext{
63 See Mazzarino (1943) 44 and $5 \mathbf{1}^{-} 5^{2}$.

64 Sappho fr. 98b.7-9, my translation.

65 See Schlesier (2013). However, in the corpus of Sappho's poems there are no indications that the poet was a courtesan: frs. 1 (lines $21-23$ about reciprocity), 5 (especially lines 6 8 ) or the Brothers Poem (esp. lines 10-12 and 17-24) show her firm adherence to the

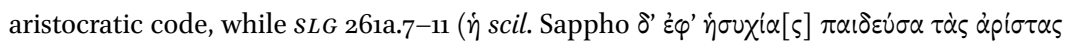

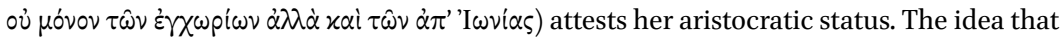
Sappho was a courtesan is probably a rereading by comedy and Athenian symposia: see Wilamowitz (1913) and Yatromanolakis (2007). See also Bierl's contribution to this volume (on the Brothers Song).
} 
context that implies the concurrent presence of male and female 'friends' along with relatives outside a sacred place.

In light of this reconstruction, I suggest that the audiences of fragment 98 and the Brothers Poem are similar. Of course, in the Brothers Poem the composition of 'we' in lines 13 and 21 is problematic, as is a suitable context for its performance. To form an idea of the composition of Sappho's audience here, we have to consider the entire corpus of her poetry, with an eye to whether her group would have been in attendance at all her performances. In 1993 Parker proposed that Sappho had two different audiences, one that consisted of her 'friends', the other of the listeners during her professional wedding performances: he supposed that Sappho had only adult companions, and that the young women of her poems simply played an active part in wedding ceremonies. However, this division in Sappho's audience is unlikely, since fragment 27 , for example, shows that her group may be attending all her performances. This poem seems to be connected to a wedding, and was probably performed before the beginning of the ceremony (cf. $\sigma \tau \varepsilon i \chi \chi 0 \mu \varepsilon \nu$ घं ránov line 8). With regard to the audience, it is important to note that this poem shares with others in the Sapphic corpus the theme of memory (lines 45): as in fragments 16, 94, perhaps 95, and 96 we find in fragment 27 a person inviting someone to remember-or who herself remembers (see fragment 94) - a past related to sacral activities, musical performances, love, etc. These

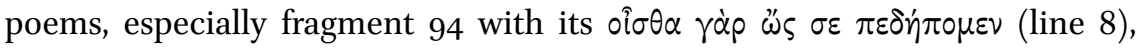
seem to refer to the relatively stable female group of Sappho's 'friends' and companions. ${ }^{66}$ So fragment 27 has a liminal position in the Sapphic corpus, between a wedding and a group's poem. ${ }^{67}$ To me this situation suggests that Sappho's group always took part in her poetical performances: fragment 27 would imply that the addressee was a member of this group who was perhaps getting married (cf. lines 8-9) and is being invited to remind the audience (line $\left.6 \varkappa \ddot{\alpha} \mu \mu^{\prime}\right)$ of the time when she was a child. If we accept this reading, it is possible to dismiss Parker's idea of two Sapphic audiences, because the weddings concerned women who were members of Sappho's group. I have accordingly proposed that the core of Sappho's audience was stable, as was that of Alcaeus' according to Rösler's (1980) reconstruction. This would mean that Sappho's female 'friends' are likely to have attended the performance of the Brothers Poem.

66 See Caciagli (2011) 43 and n. 2.

67 See Caciagli (2009). 
This general understanding of Sappho's audience provides a basis on which to reconstruct the listeners of the Brothers Poem. To complete the picture, we must add that one of the criteria for being numbered among Sappho's 'friends' was possibly membership in the political faction to which her family belonged. I mean by 'faction' a $\sigma \tau \dot{\alpha} \sigma \varsigma \varsigma$, i.e. an alliance of aristocratic families of which the masculine $\dot{\varepsilon} \tau \alpha \iota p \varepsilon i \alpha \iota$ were the leadership; of course, the women did not have a political role, but they could share the ideological principles and the political interests of their families. ${ }^{68}$ In this regard, it is possible to compare Sappho fragment $71^{69}$ with Alcaeus fragment 112 and its scholia: from the elements provided by them, it can reasonably be conjectured that recruitment by groups that were in rivalry with Sappho's or Alcaeus' was a consequence of familial affiliation. In the case of fragment 71, the poet blames Mika for choosing the

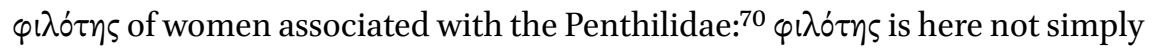
love', especially if we consider that it designates a relationship between a woman and a female group. This 'friendship' was the relationship that binds the members of male hetaireiai as well as Sappho's group. ${ }^{71}$ Sappho's or Alcaeus' rival group is identified through a patronymic, so it may be inferred e.g. that the affiliation with the Penthilidae is the key factor for inclusion in the group of Andromeda or Gorgo. This situation, which is probably comparable to Sappho's or Alcaeus', does not mean that all the members of this kind of group were relatives; in fact, a faction consisted of both relatives and allies, the latter obviously potential relatives through matrimonial politics. ${ }^{72}$

These considerations make it possible that Sappho's relatives were present at the performance of the Brothers Poem, especially if the addressee is Eurygyios. This interpretation helps to reconstruct the audiences of the poems of Sappho that concern Charaxos and more generally her family poems. These poems share similar themes, i.e. the social status of Sappho's family, although they probably had different contexts. If we accept the idea that fragment 17 is connected to Charaxos, this latter poem may be part of this scenario.

68 See Caciagli (2011) 201-232; see also Aloni 1983.

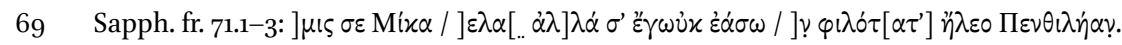

70 See Ferrari (2007) 33, 59-61.

71 See Caciagli (2011) 56-88. Thgn. (1311-1318) is a significant parallel for Sapph. fr. 71, espe-

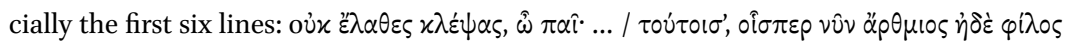

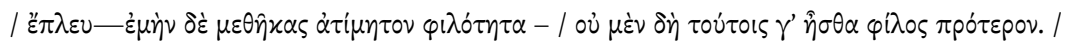

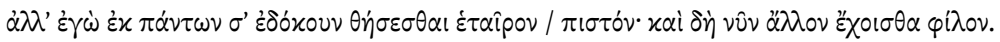

72 This reconstruction explains the frequent betrayals that characterise male and female groups of friends: when an alliance between two factions was broken, some members of these groups changed communities. 


\section{Prayers for Charaxos and Their Audience}

Given the possible connection between Sappho's family poems and an extended audience, including her family members, it is interesting to analyse fragments 5 and 15 in order to reconstruct their audience. Formally, these fragments are prayers in the same way as fragment 17 , and they too concern Charaxos' situation, even though they possibly refer to two different moments. Fragment 5 is challenging, even after Burris, Fish, and Obbink (2014) have established the text of its incipit and ruled out Cypris: in fact, the Anrede in the

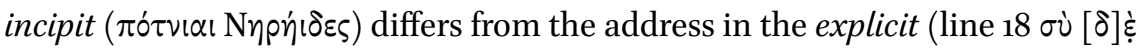
Ku $\pi[\rho] !$ ). This is a very strange feature for a prayer, given the ring composition that normally occurs in this kind of text. Although it is difficult to distinguish between a real prayer and a fictional one, I suggest that this poem is a real prayer: firstly, the incipit of the poem is characterized by the same deixis as Alcaeus fragment 129 or Sappho fragments 2 and 17, which were performedin my view - in sacral places. ${ }^{73}$ The structure of fragment 5 is congruent with a real prayer: there are addresses in incipit and in explicit and a series of requests to the gods. The differences between this poem and e.g. Sappho's fragment 1 is evident: in this latter poem the name of the beloved is missing, while the real core of the song is Aphrodite's justice that the poet states in lines 21-24. In fragment 5, the usual deity of Sappho's poetry, Aphrodite, is summoned, but with an epiclesis, Cypris, that in general implies her connection with the sea. ${ }^{74}$

The poet makes two requests to the goddess: firstly, that Charaxos arrives at Lesbos without harm (line $1 \dot{\alpha} \beta \lambda \dot{\alpha} \beta \eta[v)$, assuming that a sea trip is also suggested by the address to the Nereides in line 1; secondly, that 'as much as he has previously gone wrong grant atonement for it all', i.e. probably that he ends his relationship with Doricha. In this context, it is suggestive that Sappho uses a lexis close to a male and political context: she talks about $\alpha$ ví $\alpha$ not in an erotic sense, and about $\varphi$ i $\lambda$ or and ${ }^{\prime \prime} \chi \theta \rho o r$ in a manner similar to that of e.g. Solon (fragment 13.5-6), when she asks her brother to increase her $\tau \mu \eta^{\prime}$ and hints at the $\pi 0 \lambda i \tau \alpha$, whose opinion was clearly important for an aristocrat, as Archilochus (fragment 14) also suggests. So the poem does not only concern love, which would normally be the case when Sappho mentions Aphrodite, but the social status of Sappho's family. As for the listeners, I suggest that the theme of this poem points to an audience that consisted of Charaxos' male

73 See Caciagli (2011) 136-162.

74 See Rougé (1975) 207-208. 
relatives and 'friends, ${ }^{75}$ people who were deeply affected by Charaxos' affair and its social, economical and political consequences. In any case, the address to Cypris, the goddess of Sappho's poetry, can support the idea that her group was present too: it addresses the same divinity with a different function than is usual, i.e. Aphrodite may be here $\varepsilon \ddot{v} \pi \lambda$ ol $\alpha$ as in fragment 15.2. This deity played an erotic role in Charaxos' story anyway, especially because the love between Charaxos and Doricha is probably one of the reasons for the reproaches made by the citizens (line 14).

It is possible to make similar comments about fragment 15, where Aphrodite, again with the epiclesis Cypris, has a more explicitly erotic role. If Fränkel's (1928) reconstruction has merit, lines $1-8$ concern a sea journey, as $\varepsilon \dot{v} \pi \lambda \lambda_{0}[\alpha$ in line 2 and $\lambda i[\mu]$ gvos in line 7 suggest. The circumstances of fragment 15 are different from those of fragment 5 : the former sounds like a wish that Charaxos not fall in love with Doricha again, possibly during another stay in Egypt; in fragment 5, Sappho prays to Aphrodite to lead her brother to Lesbos without harm. Fragment 15 is possibly more personal than fragment 5 , where the poet only hints at Charaxos' mistakes (in line 5), though the remarks about the audience of fragment 5 likely apply to fragment 15 too. An important question would be the kind of context that these fragments imply, since a prayer does not necessary entail a sacred place in ancient Greece. I would only suggest that fragment 5 sounds more like a proper prayer; the deixis in line 2 is potentially evidence for a shrine, especially when we consider that poems like Alcaeus fragment 129 or Sappho fragment 17 are characterised by strong deixis. However, the limited nature of the information available suggests caution in this regard. Finally, fragment 5 and 15 may be similar to fragment 17 in context and audience, although they are addressed to different goddesses: given my reading of fragment 17 , this poem and fragment 5 seem to share a similar occasion, i.e. a prayer to a goddess for Charaxos's safe return from Egypt.

\section{The Audience of Sacral Poems}

The analysis of Sappho fragment 5, 15, and 17 raises the question about what kind of the audience might be implied by poems that relate to performances in sacred places. It is probable that no Greek shrine was 'private', in the sense of

75 The word $\varphi$ i $\lambda$ o in fr. 5.6 may refer to Charaxos' friends, i.e. his $\dot{\tau} \alpha \hat{p} \rho \circ$, or the 'friends' of Sappho's family: at any rate, regarding the identity of the $\varphi$ i $\lambda$ ol, the lexis of this poem perhaps suggests that Sappho's audience included men. 
being open only to a particular faction, family, hetaireia, or other group with a similarly narrow composition; this is particularly true of Messon, which was the federal sanctuary of the Lesbians from the archaic to the Roman age. Apart from fragment 17 , the poems associated with this shrine show different situations anyway. In fragment 129 Alcaeus probably refers - through $x \eta \dot{v} v \omega \nu{ }^{\prime} E[\rho i v v v] \varsigma$ in line 14-to the men who died because of Pittacus and reminds his audience of the oath that established the alliance between Alcaeus' and Pittacus' hetaireiai. ${ }^{76}$ The occasion of fragment 129 is a special one, not linked to the festival calendar of Messon. This situation possibly explains the makeup of the audience: Alcaeus' group probably found in Messon asylum from Myrsilus' guards, who followed this group from Mytilene to Pyrrha after Pittacus' betrayal. ${ }^{77}$ The audience thus seems to consist of Alcaeus' companions, who have an interest in the oath described by the poet. In fragment $130 \mathrm{~b}$ Alcaeus complains about his loneliness and his witnessing at a distance of the female Kallisteia; from fragment 13oa we know that the poet was alone, without 'friends' (line 1, $\alpha \chi \nu \dot{\alpha}-$

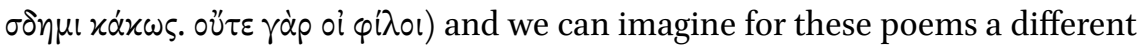
audience than of fragment 129. With regard to fragment $130 \mathrm{~b}$ in particular, we can imagine that Alcaeus' hetaireia was partially scattered, with the result that the poet felt isolated.

Leaving aside Messon, other poems in the corpora of Sappho and Alcaeus may be connected to sacral contexts, such as Sappho fragments 1 and 2 (prayers to Aphrodite) or Alcaeus fragments 34A (to Dioscouroi), 45 (to Ebros) and 303 Ab (to Apollo = Sappho fragment 99.10-21 L.-P.). Moreover, Sappho fragment 44a and Alcaeus fragments 307 and 308 may be interpreted as $\pi$ pooí $\mu \alpha$. However, it is sometimes difficult to understand whether these poems are performed in a sacred place or not so that it is problematic to assign these poems to a specific context and audience: in fact, the Greeks could pray in and outside a sanctuary, as sympotic hymns show. ${ }^{78}$ Sappho fragment 1 well illustrates this problem, because there are not deictic or pragmatic elements to connect the poem to a specific context. Of course, it is possible to speculate about the audience by analysing the theme of the poem: since in line 24 the addressee is a women and lines 19-24 seem to display the ideological summa of Sappho's

76 Mazzarino (1943) 39-41 suggests that Pittacos was a member of Alcaeus' $\dot{\tau} \tau \alpha \iota p \varepsilon i \alpha$. However,

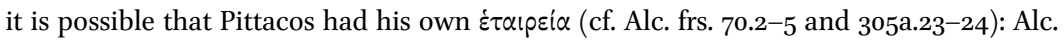
fr. 129.14-20 may refer to the $\sigma v v \omega \mu \circ \sigma i \alpha$ between Pittacus and Alcaeus' groups, i.e. a sort of

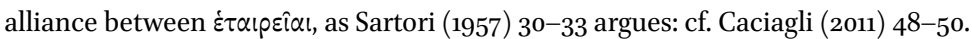

77 See schol. Alc. fr. 60.

78 See Fabbro (1995) XIX-XXIII. 
group ${ }^{79}$ the audience of fragment 1 may be congruent with female friends of the poet. Alcaeus fragments 34A and 45 are probably invocatory hymns, but it is impossible to understand the connection with the hic et nunc on account of the text's poor condition. Of course, these hymns may be sympotic poems, if we follow Rösler's idea that Alcaeus' poetry was entirely sympotic, ${ }^{80}$ but it is also possible to postulate a religious context involving audiences more extended than the hetaireia and including the wider community of citizens. The same goes perhaps for Sappho fragment 44a and Alcaeus fragments 307 and 308. Sappho fragment 2 provides more elements to reconstruct its audience and context: the poet probably describes a sacred है $v \alpha \nu \lambda \circ \varsigma$ dedicated to Cypris, where the goddess is summoned to perform a libation. ${ }^{81}$ Sappho sketches the place of the poetic performance, with apple trees, streams, roses, meadows, horses, spring flowers and breezes, all of which have erotic associations, which is possibly a priori evidence that the target audience is Sappho's group, for whom Eros is essential. This element is obviously not explicit, but the theme of this poem probably supports this reconstruction. ${ }^{82}$ Finally, it is possible that Alcaeus fragment 303Ab (= Sappho fragment 99.10-24 L.-P.) was performed in the temple of Apollo Napaios, ${ }^{83}$ near Messon, but the text of this fragment is in a terrible state, so that it is impossible to speculate about its audience. Finally, a sacral context does not imply a specific audience, because its composition depends on the reasons that urge people to pray.

\section{The Audience and the Occasion of Sappho Fragment 17}

The analysis that we have provided of fragment 17 as well as fragments 5,15 and the Brothers Poem implies that these poems are not fictional. In this regard, I should like to add that, apart from rare examples, it is quite impossible to determine whether the content of a poem is fictional or not. Greek poems are in general ambiguous: this situation is not only the consequence of the extremely fragmentary nature of archaic Greek poetry, but also of the fact that this kind of poetry was intrinsically allusive because most of the contextual elements, such as references to an historical moment, the occasion or the

\footnotetext{
79 See Caciagli (2011) 77-88.

$80 \quad$ See Rösler (1980) 33-41.

81 See Caciagli (2015).

82 In this respect it may be significant that Athenaeus (11.663e) comments on the quotation

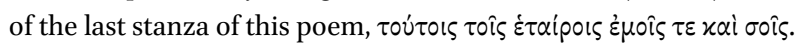

83 See Koldewey (1890) 44-46.
} 
place of the performance, were self-evident to the audience, so that the poet did not need to make them explicit. Obviously, this situation is significant for the first performance, which is the object of my analysis of fragment 17. The poet, for example, does not mention here the name of Charaxos or his story, as she does not in fragment 5 , because her audience knows the occasion of the performance.

So, given that the historical evidence for archaic Greece is fragmentary, does a pragmatic approach to Greek poetry make sense? In my view, the point is not actually to divine the one correct context for a poem, but simply to raise the question about the context, for which the pragmatic and anthropological approach seems necessary. If this approach is not sufficient to reconstruct the context, we can discover it through an analysis of the themes of a poem, which has to complement the pragmatic approach. Such an analysis, of course, runs the risk of subjectivity, but I suggest that 'non-pragmatic' approaches run a greater risk, i.e. of being anachronistic. Consider Anne Pippin Burnett's (1983) charge against 'occasionalist' scholars who 'refuse the archaic singers the freedom to create their own fictions': in fact, 'archaic poets, like poets everywhere, invented both ego and occasion when they composed their songs' (p. 6). ${ }^{84}$ This approach may generate anachronisms by attempting to associate social phenomena that belong to fundamentally different historical moments and societies.

A similar risk attends if scholars are insufficiently attentive to the performative context when they compare literary topics or themes of different poets, because in archaic Greece the meaning of a topic or a theme could change according to the occasion. Of course a pragmatic approach does not exclude fictional elements in archaic Greek poetry: ${ }^{5}$ Sappho fragment 1, for instance, seems to be fictional, especially because the poet does not mention an essential element for a real prayer, i.e. the name of her beloved in the request to Aphrodite. However, the question to be raised is the following: what kind of fiction would emerge from archaic Greek poetry? If we postulate that Greek poems are not 'literature' in the modern sense, but acts of worship or songs that were part of social phenomena like symposia, their link to the concrete context of the performance has to be postulated, even if the content is fictional. For example, fragment 31 is probably fictional, but the opening scene can hint

\footnotetext{
84 On the New Critical approach hidden beneath Burnett's analysis see Rösler (1984) 202203.

85 See Latacz (1985), Rösler (1990), and Calame (2005) 13-40, who provides a methodological framework for these questions.
} 
at a typical one in the life of Sappho's group and the sufferings of the poet may be ideologically paradigmatic for her audience, probably in regard to occasion that line 17 probably implies.

Given this methodological framework, I suggest that, in the case of Sappho fragment 17 , we have more information than about other poems to recreate the context, the occasion and the audience. In regard to the context, there is a fairly coherent corpus of poems related to Messon, with supplementary epigraphic and literary testimonia that make it possible to get a good sense of what this sanctuary was like; further, we have many pieces of information regarding Charaxos' affair, so a poem that addresses the difficulties of a sea trip naturally suggests Sappho's brother: both the myth about the nostos of the Atreids and the comparison with the Brothers Poem, fragment 5 and 15 may confirm this suggestion.

As for the audience of fragment 17, we have initially postulated that the core of Sappho's audience always attended her performances. However, a survey of her family and sacral poems shows that the composition of the audience depends on occasion. This observation is relevant to Sappho fragment 17 if we accept that this poem refers to Charaxos' affair. Lines 11-20, though fragmentary, are crucial to understanding the audience of this poem. A first person plural (line 11) says that 'we' now perform in accordance with the heroic past (line $12 \tau \dot{0} \pi \dot{\alpha} \lambda .[\alpha / \circ v) ; 86$ the young and adult women of line 14 perhaps play a role in this performance, while the present festival, which reenacts the heroic one, possibly concerns holy things. So the prayer would be a request to Hera for a safe trip: just as she did for the Atreids, the goddess now must help Charaxos to return home and thereby reach (e.g. $\dot{\alpha} \pi i x \varepsilon \sigma \theta \alpha$ l) the place where fragment 17 is performed. Given these elements, it is likely that Sappho's group was present

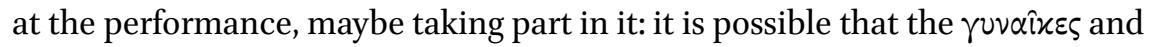
$\pi \alpha p \theta \varepsilon \dot{\varepsilon}$ ol of line 14 were members of this group, especially if this was-as has been suggested - a female hetaireia consisting of both young and adult women. This hypothesis is especially appealing if the members of Sappho's group were actually recruited from a family or an alliance of families, because they would probably have been affected by Charaxos' behaviour. Thus, though Sappho's major audience probably consisted of her 'friends,' it is possible that a performance could sometimes be opened up to other listeners according to the occasion, potentially even to her fellow citizens, so that, in the present case, the members of her faction may have been in attendance at the performances that speak of Charaxos' affair. 
Finally, as for the occasion of fragment 17, we have ruled out that it was performed during the Kallisteia because its mythical part does not concern beauty but difficulties in a sea trip. However, the fact that the poet evokes a festival in line 2 suggests that this poem was performed in connection with a specific moment in the sacral calendar of Messon: in spite of the apparently 'private' aim of this prayer, its performance was probably radically different from that of Alcaeus fragment 129, whose occasion was linked to an accident that affected the usual audience of this poet, that is to say his hetaireia. 